\title{
DUROC AS A TERMINAL SIRE LINE FOR FATTENING PIGS PRODUCTION
}

\author{
Dragomir Lukač ${ }^{1}$, Vitomir Vidović ${ }^{1}$, Vladislav Višnjić ${ }^{2}$ Jovanka Krnjaić ${ }^{3}$ \\ ${ }^{1}$ University of Novi Sad, Faculty of Agriculture, Department of Animal Science, \\ Trg Dositeja Obradovića 8, 21000 Novi Sad, Serbia \\ ${ }^{2}$ Carnex Ltd. Meat Industry, Kulski put 26, 21400 Vrbas, Serbia \\ ${ }^{3}$ Delta Agrar, Napredak a.d., Golubinački put bb, 22300 Stara Pazova, Serbia \\ dragomir.lukac@stocarstvo.edu.rs
}

\begin{abstract}
Aim of this paper is to show productive results of fattening pigs obtained from crosses of Duroc sires, and $F_{1}$ sows which are obtained from mating of Landrace and Yorkshire. Investigation is conducted on one commercial farm in which production undergoing trough all technological phases, from piglets production on the beginning till the final product which is fattening pigs. Growth traits were investigated on 3093 piglets which were divided in seven facilities. In lactation period of 26 days, gained body weight was $7.36 \mathrm{~kg}$. In growing period which lasted 58 days, crosses obtained from Duroc sires have achieved daily weight gain of $0.50 \mathrm{~kg}$ and average body mass of $29 \mathrm{~kg}$. In fattening period which lasted 85 days, average daily gain was $0.83 \mathrm{~kg}$ with achieved body mass of $70.89 \mathrm{~kg}$. At the end of fattening period, fatlings have achieved final body mass of $107.30 \mathrm{~kg}$ in period of 159 day in total, with $59.70 \%$ of meat in carcass. Total feed consumption per fatlings was $192 \mathrm{~kg}$. Total losses in fattening period were $5 \%(2.8 \%$ mortality and $2.2 \%$ economic slaughters). This high level of productive performance, combined with the high meat percentage in carcass of fattening pigs, lids to a conclusion which explain the popularity of the Duroc breed as a sire line in many countries.
\end{abstract}

Key words: body weight; Duroc; fattening pigs; terminal sires

\section{ДУРОК КАКО ТЕРМИНАЛНА ТАТКОВСКА ЛИНИЈА ЗА ГОЈНОТО СВИНАРСКО ПРОИЗВОДСТВО}

\begin{abstract}
Целта на овој труд е да се прикажат производните резултати кај гојни свињи, добиени при вкрстување на нерези од расата дурок и маторици од генерацијата $F_{1}$, кои се добиени со парење на ландрас и јоркшир. Испитувањето е реализирано на една комерцијална фарма, на која постојат сите технолошки фази на производство, почнувајќ́ од производство на прасиња, па сѐ до производство на финалниот производ, гојни свињи. Беше испитуван прирастот кај вкупно 3093 прасиња поделени во 7 групи. Во текот на лактацискиот период од 26 дена прирастот во телесната тежина изнесуваше 7,36 kg. Во текот на гојниот периодкој изнесуваше 58 дена, мелезите кои беа добиени од дурок-татковци постигнаа дневен прираст од $0,50 \mathrm{~kg}$ и просечна телесна маса од $29 \mathrm{~kg}$. Во текот на гојниот период, кој изнесуваше 85 дена, просечниот дневен прираст изнесуваше $0,83 \mathrm{~kg}$ со постигната телесна маса од $70,89 \mathrm{~kg}$. На крајот од гојниот период гоениците постигнаа финална телесна маса од $107,30 \mathrm{~kg}$ за вкупен период од 159 дена, со 59,70\% на месо во трупот. Вкупата консумација на храна по гоеник изнесуваше $192 \mathrm{~kg}$. Вкупните загуби во гојниот период беа $5 \%(2,8 \%$ смртност и 2,2\% економски колења). Ваквото високо ниво на производни перформанси, комбинирано со висок процент на месо во трупот кај гоениците, дозволува да заклучиме дека тоа е причина зошто расата свињи дурок како татковска линија е популарна во многу земји.
\end{abstract}

Клучни зборови: телесна тежина; дурок; гојни свињи; терминални татковци

\section{INTRODUCTION}

Awareness of the negative genetic dependencies between fertility and milk production traits on one side and meatiness properties on the other, led to the creation of specialized breeds and lines of pigs in the production of hybrid porkers, whose selection criteria in choosing the parents differ significantly. In most European countries, including Republic of Serbia, have crystallized the two fertile 
breeds - Landrace and Yorkshire, which are used for the production of $F_{1}$ dams for mating with terminal boars breed such as Duroc, Hampshire and Pietrain $[18,3,2]$, as well as their $F_{1}$ product (synthetic boars containing recombination of desirable genes for most properties). In these cross schemes, heterosis of dams is maximized, while the boars side achieves a high selection differential. Offspring obtained in this way is numerous, dams have plenty of milk, and fattened in feedlot are uniform, characterized by good health, resilience, efficient feed utilization and rapid growth. The main reason for such crossing combination is profit, i.e. to realize greater growth with the lowest possible cost.

However, in Europe and in Serbia, the most widely used terminal sire breed is Duroc, while the Hampshire sire breed are used in smallest intensity. One-way selection on the meatiness in Pietrain pig breed has led to certain physiological disorders such as occurrence of genes for stress, heart problems, occurrence of pale, soft and exudative meat (PSE), reduced fertility and milk production of sows, which is why this breed is almost not used as a terminal breed, except in situations where we do not have sires of other two terminal breeds $[8,9]$.

Research of many authors $[14,5,8]$ have shown the advantage of the Duroc breed for growth and feed utilization, and confirmed the advantage of this breed when in question comes meat quality. Several sources suggest that this breed also brings interesting advantages on hardiness and social behavior. Regarding carcass quality, Duroc has shown equivalent or better performances than most of the other sire breeds $[9,16]$. Compared to Pietrain and Hampshire, Duroc sired hogs show slightly lower levels of lean content but higher dressing yield, while pork quality is usually in favor of Duroc, especially the parameters as marbling, tenderness and juiciness $[5,12]$. The Canadian Genetic Swine Improvement Program has contributed to important genetic gains on growth ( -13 days to $100 \mathrm{~kg}$ in the last 10 years) and carcass quality $(+1.7 \%$ of lean content in the last 10 years) in the Duroc breed.

This high level of performance, combined with the excellent meat quality potential of the breed, results in a very good paternal type for all traits of interest, which mainly explain the popularity of the breed as a sire line in many countries. Based on all the above, the aim of this paper is to present the feasibility of Duroc boars usage in fattening pigs production through production results of offspring during fattening period.

\section{MATERIALS AND METHODS}

Production results of Duroc sires offsprings were monitored on one commercial farm of capacity of 1100 hybrid sows, during the year 2011. The farm is of closed type, where production runs through all technological stages from piglets production to the final product, i.e. fatlings. Production parameters were observed in $3093 \mathrm{~F}_{1(\mathrm{~L} \times \mathrm{Y})}$ hybrid crossing sows with Duroc boars. After birth, and based on the buildings on the farm, seven experimental groups of pigs were formed, which went through all the stages of technological production. During the observation period, care and nutrition was identical, for all groups within the same category, as well as environmental conditions on the farm. Piglets nutrition with prestarter mixtures in farrowing started on the fifth day after birth. After moving from farrowing pens in breeding facilities, piglets continued to consume prestarter mixture with $19.5 \%$ crude protein, and after that, starter diets containing $19 \%$ crude protein. For pigs nutrition in fattening phase, three mixtures were used: grower, finisher 1 and finisher 2 , with $17 \%, 16 \%$ and $14 \%$ of crude protein, respectively.

Phenotypic parameters of fattening traits, which describe the distribution frequency of measurements in different experimental groups, were calculated using the standard formula of descriptive statistics in the software program Statistica 12.

\section{RESULTS AND DISCUSSION}

Today, for pig producers challenge is to on the most economical way in the shortest possible period of time provide the final product, porkers that have the highly-anticipated and good meat quality. Three breed cross is the most common scheme of breeding pigs, which leads to the maximum manifestation of hybrid vigor or heterosis in fattening pigs obtained from mating terminal boars with sows $F_{1}$ generation obtained by crossing of Landrace and Yorkshire breeds. The result of this type of crossing is the improvement of fattening characteristics in offspring, such as growth and feed conversion ratio in certain production phases which are shown in Tables 1 and 2, as well as resistance to disease and a lower percentage of mortality shown in Table 3.

Based on the average weight of the $7.36 \mathrm{~kg}$ and the interval ranging from 6 to $8.7 \mathrm{~kg}$, which was in a relatively short suckling period of only 26 
days, it can be concluded that the piglets achieve satisfactory body weight, which will have a large positive effect on the subsequent body gain, better adaptation to new nutrition phases and reduced mortality percentage. Piglets which were heavier at weaning were also heavier at every subsequent age [7]. Weight of pigs at weaning depends on the birth weight of piglets, feeding and length of lactation period [17, 11, 20, 19]. Pigs do not poses ability for compensating live weight differences between litter mates during growth period such as case with cattle and sheep. Therefore, any reduction in its weight gains from birth onwards will have an amplified detrimental effect on growth from weaning to slaughter [4]. These are further arguments to select for an increased minimal birth weight.
After the lactation period of 26 days, piglets were moved to rearing, where they have remained for the next 58 days where they achieved body weight of $29.0 \mathrm{~kg}$ with a coefficient of variation of $7.54 \%$ which ranged from 20.8 to $34.1 \mathrm{~kg}$. Average daily gain for all groups in this phase amounted to $0.5 \mathrm{~kg}$.

With a total of 74 days of age and average body weight of $36.4 \mathrm{~kg}$, all pigs were transported to facilities for fattening, where reside the next 85 days. In this period, pigs achieved an average body weight of $70.9 \mathrm{~kg}$ and daily gain of $0.83 \mathrm{~kg}$. After completion of this phase, pigs were about 159 days old, with the body weight of $107.3 \mathrm{~kg}$, with variations coefficient of $2.45 \%$, while body weight at slaughter ranged from 100 to $115 \mathrm{~kg}$.

Table 1

Production results of Duroc sires offspring

\begin{tabular}{lcccccccc}
\hline \hline \multirow{2}{*}{ Traits } & & $\bar{X}$ & $\begin{array}{c}\delta_{\bar{X}} \\
(\mathrm{~kg})\end{array}$ & $\begin{array}{c}\delta \\
(\mathrm{kg})\end{array}$ & $\begin{array}{c}V \\
(\%)\end{array}$ & $\begin{array}{c}\text { Min } \\
(\mathrm{kg})\end{array}$ & $\begin{array}{c}\text { Max } \\
(\mathrm{kg})\end{array}$ \\
\hline Weaning body weight & 3093 & 7.36 & 0.03 & 0.46 & 6.25 & 6.00 & 8.70 \\
Weight gain on suckling & 3093 & 0.28 & 0.00 & 0.01 & 3.57 & 0.23 & 0.34 \\
Weight in nurture period & 2982 & 29.03 & 0.18 & 2.19 & 7.54 & 20.80 & 34.10 \\
Gain in nurture period & 2982 & 0.50 & 0.00 & 0.03 & 6.00 & 0.35 & 0.59 \\
Weight at the end of nurture period & 2982 & 36.40 & 0.17 & 2.08 & 5.70 & 29.00 & 42.00 \\
Body weight in fattening & 2833 & 70.90 & 0.28 & 3.38 & 4.76 & 61.80 & 84.00 \\
Gain weight in fattening & 2833 & 0.83 & 0.00 & 0.03 & 3.61 & 0.73 & 0.96 \\
Final body weight & 2833 & 107.30 & 0.22 & 2.63 & 2.45 & 100.00 & 115.50 \\
\hline \hline
\end{tabular}

$\bar{X}$ - mean; $\delta_{\bar{X}}$ - mean standard error; $\delta$ - standard deviation; $V$ - variation coefficient

Table 2 gives one of the most important indicators in pigs fattening, from which economic and fattening profitability depends on. From the same table can be concluded that the offspring of Duroc sires breed have achieved remarkable product results. Life weight gain was $0.63 \mathrm{~kg}$, with the average feed consumption of $2.25 \mathrm{~kg}$, with a conversion ratio of $2.72 \mathrm{~kg}$. Total feed consumption per pig was about $192 \mathrm{~kg}$. These data have very important role in pig production, knowing that diet is one of the most important issues in cost calculating, knowing that the greatest costs on the farm is feed. On the slaughter line, percentage of carcass meat was determined and it was $59.7 \%$. In a survey of scientists from the Atlantic Swine Research Partnership, which were aimed at comparing the offspring of boars Yorkshire, Landrace and Duroc in several properties.
Table 2

Production indicators of fattening pigs during the fattening period

\begin{tabular}{lr}
\hline \hline Traits & Mean \\
\hline Life gain, $\mathrm{kg}$ & 0.63 \\
Average feed consumption, $\mathrm{kg}$ & 2.25 \\
Feed conversion ratio, $\mathrm{kg}$ & 2.72 \\
Feed utilization per one fatling pig, $\mathrm{kg}$ & 192.22 \\
Meat percentage in carcass halfs, \% & 59.70 \\
\hline \hline
\end{tabular}

The main differences were observed in weight gain. The Duroc boars offspring was observed higher daily gain $(1.04 \mathrm{~kg})$ and lower feed conversion ratio (2.51) compared with Yorkshire (daily 
gain $0.94 \mathrm{~kg}$ with a feed conversion ratio of 2.7) and Landrace (daily gain $0.90 \mathrm{~kg}$ with a feed conversion ratio of 2.55) offspring, while the percentage of meat was almost the same in all three breeds (about 61\%). One of the greatest experiment in America as part of the National Genetic Program of 1994-1995, by the American National Association of pig farmers which was conducted to compare Duroc with the other terminal breeds. In this experiment, the Duroc boars offspring were topranked, above average economic index, which includes feed conversion and body weight gain, while the meat quality was assessed as very high compared to the other terminal sire breeds. In an experiment conducted on the Michigan State University [6] in offspring of Duroc and Pietrain boars, properties of carcass and meat quality was observed. Duroc boars offspring had a longer (86.9 $\mathrm{cm}$ ) and heavier carcass halves and a slightly lower percentage of meat in relation to the Pietrain boars offspring $(84.8 \mathrm{~cm})$. Flesh color, intramuscular fat, firmness and meat spoilage were more favorable in offspring of Duroc boars. Duroc offspring dressing percentage stood at $73 \%$, with $51 \%$ of meatiness and loin clay of $2.88 \%$, while the Pietrain offspring had a yield of $74 \%$ with $53 \%$ meatiness and loin drip loss of $3.80 \%$.

Mortality degree in experimental groups at this stage is shown in Table 3. From the table it can be seen that the number of fattening pigs at the entrance was uniform. Upon completion of the fattening period, mortality percentage was $2.8 \%$, while the percentage of economic slaughter was 2.2 , so that the total loss in fattening was $5 \%$. Similar trend was established also by Henryon et al. [13] and Saintilan et al. [15].

In Duroc breeds in the last ten years, significant progress, especially in daily weight gain and carcass quality was established. In Canada, for the past 10 years, fattening period up to $100 \mathrm{~kg}$ body weight was reduced by 13 days and the percentage of meat has increased by $1.7 \%$ [1]. Such high performance combined with great quality meat as a result led to Duroc boars is used as the terminal breeds in many countries. It was found that Duroc boars can have a significant effect on carcass and meat quality of their offspring.

In a study by Eggert et al. [10] derived on the offspring of Duroc, Pietrain and Yorkshire, Duroc offspring had significantly higher daily gain, lower feed conversion ratio and increased daily feed consumption, compared to Yorkshire and Pietrain offspring, while the Pietrain offspring had a significantly larger area of large back muscles.
Table 3

Mortality rate and economic slaughter

\begin{tabular}{ccccccc}
\hline $\begin{array}{c}\text { Number } \\
\text { of fatlings at } \\
\text { the beginning }\end{array}$ & & & & & & \\
slaughter & $\begin{array}{c}\text { Weight of } \\
\text { economic } \\
\text { slaughter }\end{array}$ & $\begin{array}{c}\text { Number } \\
\text { of fatlings at } \\
\text { the end of } \\
\text { fattening }\end{array}$ \\
\hline № & № & $\%$ & № & $\%$ & kg & № \\
\hline 428 & 17 & 4.0 & 10 & 2.3 & 41.00 & 401 \\
424 & 12 & 2.8 & 10 & 2.4 & 43.20 & 402 \\
431 & 17 & 3.9 & 9 & 2.1 & 40.50 & 405 \\
411 & 8 & 1.9 & 13 & 3.2 & 39.40 & 390 \\
435 & 13 & 3.0 & 11 & 2.5 & 42.10 & 411 \\
428 & 8 & 1.9 & 7 & 1.6 & 44.00 & 413 \\
425 & 8 & 1.9 & 6 & 1.4 & 46.00 & 411 \\
2982 & 83 & 2.8 & 66 & 2.2 & 42.3 & 2833 \\
\hline \hline
\end{tabular}

In the research of Suzuki et al. [16], Duroc breed was exposed during the seven generations of selection using selection index and BLUP for daily gain, muscle surface area, dorsal fat and intramuscular fat. The content of intramuscular fat is increased to $5 \%$, in more than 7 generations, but is associated with an increase in weight gain and back fat. Tenderness of the meat was improved, but at the cost of increasing the amount of surface area of dorsal fat and muscle areas.

\section{CONCLUSION}

The main reason for fattening pigs breeding is that profit i.e. realization of greater growth and quality of the final product with the lowest possible cost. This can only be achieved by using different methods of selection and crossing, where the main goal is crossing of two or more breeds of pigs, manipulation of their genetic basis, and creation of new lines of cross pigs i.e. hybrids, for increase the volume, improve quality and make economically efficient pork production. From our own results and research and study of many other authors, we can conclude that the Duroc boars as terminal breeds, is one of the better choices as terminal breeds in commercial production systems. Many studies have shown the advantage of using Duroc breed in crosses for growth and feed conversion ratio improvement, and confirmed the advantage of the breed on meat quality.

Acknowledgments: Research was financially supported by the Ministry of Education, Science and Technological Development, Republic of Serbia, with in the project TR 31032. 


\section{REFERENCES}

[1] Atlantic Swine Research Partnership: http://www.asrp.ca/

[2] Bergsma, R., Kanis, E., Verstegen, M., Knol, E.: Genetic correlations between lactation performance and growingfinishing traits in pigs. Proceedings of $9^{\text {th }}$ World Congress on Genetics Applied to Livestock Production, Leipzig, Germany, August 1-6, 2010, pp. 697 (2010).

[3] Bidanel, J. P.: Genetic associations of growth and feed intake with other economically important traits in pigs. Proceedings of $9^{\text {th }}$ World Congress on Genetics Applied to Livestock Production, Leipzig, Germany, August 1-6, 2010, pp. 895 (2010).

[4] Cole, M., Varley, M.: Weight watchers from birth. New data emphasize the importance of maximizing piglet weight from birth onwards. Pig Inter., 30, 13-16 (2000).

[5] Chen, P. T., Baas, J. J., Mabry, W., Dekkers, J. C. M., Koehler, K. J.: Genetic parameters and trends for lean growth rate and its components in U.S. Yorkshire, Duroc, Hampshire, and Landrace pigs. J. Anim. Sci., 80, 2062 2070 (2002).

[6] Canadian Centre for Swine Improvement (CCSI's): http: //www.ccsi.ca

[7] Dunshea, F. R., Kerton, D. K., Cranwell, P. D., Campbell, R. G., Mullan, B. P., King, R. H., Power, G. N., Pluske, J. R.: Lifetime and post-weaning determinants of performance indices of pigs. Austr. J. Agri. Res., 54, 363-370 (2003).

[8] Edwards, D. B., Tempelman, R. J., Bates, R. O.: Evaluation of Duroc- vs. Pietrain-sired pigs for growth and composition. J. Anim. Sci., 84, 266-275 (2006).

[9] Edwards, D. B., Bates, R. O., Osburn, W. N.: Evaluation of Duroc- vs Pietrain-sired pigs for carcass and meat quality measures. J. Anim. Sci., 81, 1895-1899 (2003).

[10] Eggert, J. M., Belury, M. A., Schinckel, A. P.: The effects of conjugated linoleic acid (CLA) and feed intake on lean pig growth and carcass composition. Proceedings of Purdue Swine Day, West Lafayette, 1998, pp. 21-25 (1998).

[11] Herpin, P., Damon, M. L., Dividich, J.: Development of thermoregulation and neonatal survival in pigs. Lives. Produc. Sci., 78, 25-45 (2002).

[12] Hviid, M., Barton-Gade, P., Oksama, M., Aaslyng, M. D.: Effect of using Piétrain, Duroc or Hampshire / Duroc as sire line on eating quality in pork loin chops. Proceedings of the $7^{\text {th }}$ World Congress on Genetics Applied to Live- stock Production, Montpellier, France, August 19-23, 2002, pp. 665 (2002).

[13] Henryon, M., Sørensen, A. C., Berg, P., Nielsen, B.: Breeding pigs for resistance to disease is difficult even with genomic selection. Proceedings of $9^{\text {th }}$ World Congress on Genetics Applied to Livestock Production, Leipzig, Germany, August 1-6, 2010, pp. 854 (2010).

[14] Lonergan, S. M., Huff-Lonergan, E., Rowe, L. J., Kuhlers, D. L., Jungst, S. B.: Selection for lean growth efficiency in Duroc pigs influences pork quality. J. Anim. Sci., 79, 2075-2085 (2001).

[15] Saintilan, R., Merour, I., Schwob, S., Sellier, P., Bidanel, J., Gilbert, H.: Genetic parameters and halothane genotype effect for residual feed intake in Piétrain growing pigs. Proceedings of $9^{\text {th }}$ World Congress on Genetics Applied to Livestock Production, Leipzig, Germany, August 1-6, 2010, pp. 400 (2010).

[16] Suzuki, K., Irie, M., Kadowaki, H., Shibata, T., Kumagai, M., Nishida, A.: Genetic parameter estimates of meat quality traits in Duroc pigs selected for average daily gain, longissimus muscle area, backfat thickness, and intramuscular fat content. J. Anim. Sci., 83, 2058-2065 (2005).

[17] Tribout, T., Caritez, J. C., Gogué, J., Gruand, J., Billon, Y., Bouffaud, M., Lagant, H., Le Dividich, J., Thomas, H., Quesnel, H., Guéblez, R., Bidanel, J. P.: Estimation par utilization de semence congelée, du progrès génétique réalisé en France entre 1977 et 1998 dans la race porcine Large White: résultats pour quelques caractères de reproduction femelle. J. Rec. Porc. Fr., 35, 285-292 (2003).

[18] Vidović, V., Lukač, D., Višnjić, V., Stoisavljević, S., Stupar, M.: Effect of different selection criteria for litter size, growth performance and carcass traits improvement of the pigs in Serbia. Bul. J. Agri. Sci., 20, In press (2014).

[19] Vidović, V., Lukač, D., Štrbac, Lj., Stupar, M.: Frequency of light piglets at birth and weaning versus selection criteria. Proceedings of 6th International Scientific/Professional Conference "Agriculture in Nature and Environment Protection”, 27-29 May, Vukovar, Republic of Croatia, pp. 190-196 (2013).

[20] Wolter, B. F., Ellis, M., Corrigan, B. P., De Decker, J. M.: The effect of birth weight and feeding of supplemental milk replacer to piglets during lactation on preweaning and post-weaning growth performance and carcass characteristics. J. Anim. Sci., 80 (2), 301-308 (2002). 